\title{
Physico-Chemical and Oxygen-Hydrogen Isotopic Assessment of Bagmati and Bishnumati Rivers and the Shallow Groundwater along the River Corridors in Kathmandu Valley, Nepal
}

\author{
Rabin Malla1*, Sarita Shrestha1, Saroj K. Chapagain 1,2, Maneesha Shakya1, \\ Takashi Nakamura ${ }^{3}$ \\ ${ }^{1}$ Center of Research for Environment, Energy and Water (CREEW), Kathmandu, Nepal \\ ${ }^{2}$ Environmental Engineering and Management, Asian Institute of Technology, Klong Luang, Thailand \\ ${ }^{3}$ Interdisciplinary Centre for River Basin Environment (ICRE), University of Yamanashi, Kofu, Japan \\ Email: *rabin@creew.org.np
}

Received 29 October 2015; accepted 11 December 2015; published 14 December 2015

Copyright (C) 2015 by authors and Scientific Research Publishing Inc.

This work is licensed under the Creative Commons Attribution International License (CC BY).

http://creativecommons.org/licenses/by/4.0/

c) (i) Open Access

\section{Abstract}

The direct dumping of solid wastes into the rivers, discharge of industrial effluents together with direct discharge of domestic sewage have excessively polluted the major rivers Bagmati and Bishnumati. Groundwater along these river corridors is also affected from pollution of these rivers. Two major rivers: Bagmati and Bishnumati and shallow tube wells adjacent to these rivers were monitored for 2 years. Samples were analysed for the stable isotopes of hydrogen and oxygen $(\delta \mathrm{D}$ and $\delta^{18} 0$ ) and selected physico-chemical parameters to investigate the possible interrelationship between river water and shallow groundwater along these river corridors. The physico-chemical values revealed that shallow groundwater and river water along the Bishnumati River corridor were heavily mineralized due to direct discharge of sewage wastes into this river. The isotope compositions of river water and shallow groundwater clustered together revealed possible interrelationship between them. Some of the isotopic compositions of groundwater and river water deviated below the Local Meteoric Water Line (LMWL) indicating that the water has undergone evaporation. The isotopic and chemical results suggested possible interrelationship between river water and groundwater. Fractional contribution of the river water to groundwater was calculated based on isotopic data using mass balance approach. Results showed that shallow groundwater

${ }^{*}$ Corresponding author.

How to cite this paper: Malla, R., et al. (2015) Physico-Chemical and Oxygen-Hydrogen Isotopic Assessment of Bagmati and Bishnumati Rivers and the Shallow Groundwater along the River Corridors in Kathmandu Valley, Nepal. Journal of Water Resource and Protection, 7, 1435-1448. http://dx.doi.org/10.4236/jwarp.2015.717117 
SG1, along the Bagmati River corridor (in September 2013), was composed of approximately 30\% 40\% Bagmati River water. Similarly, shallow groundwater SG5 of Bishnumati River corridor (in September 2013), was composed of approximately $45 \%-50 \%$ river water. This result indicated that high portion of river water mixed-up with adjoining shallow groundwater along the river corridors. Further, the mix-up of the river water with groundwater can be harmful when rivers are polluted. These findings can be useful for a better understanding of hydrogeological processes at the river-aquifer interface and eventually benefit water management of the Kathmandu Valley in future.

\title{
Keywords
}

\author{
Bagmati River, Bishnumati River, Groundwater, Interrelationship, Kathmandu Valley, Stable \\ Isotopes
}

\section{Introduction}

Groundwater and surface water are the major resources for drinking, domestic and industrial uses in Kathmandu Valley. About $50 \%$ of the urban water supply in the Kathmandu Valley is derived from groundwater sources which include the shallow and deep aquifers [1] [2]. In recent years, water demand of valley has been raised by increasing population and industrial activities. The current piped water supply demand in Kathmandu Valley is 350 million litres per day (MLD), but the combined supply of groundwater and surface water in the dry season is 67 MLD. Even the supply reaches only up to 140 MLD during wet season [2]. Excessive withdrawal of groundwater causes drawdown of groundwater that can result in intrusion of nearby river water causing pollution of groundwater source [3] [4]. Besides, numerous uncontrolled waste disposal sites are located especially along the rivers where the highly permeable sediments of the riverbed pose a pollution risk to groundwater [4].

Earlier studies have reported high levels of ammonia, iron and arsenic in the deep groundwater and E. coli and nitrate in shallow groundwater in the valley [1] [2] [5]. A study undertaken by [6] found high nitrate-N concentrations ( $>10 \mathrm{mg} / \mathrm{L})$ in shallow groundwater particularly in the northern areas of the valley. The source of nitrate contamination for the shallow aquifers in Kathmandu Valley is reported mostly due to septic tanks, poorly managed sewer pipes and disposal of solid wastes. In addition, an investigation using nitrate- $\mathrm{N}$ and oxygen isotope concentrations to trace sources also revealed that human waste is the major source of nitrate contamination in the shallow groundwater of Kathmandu [7].

Similarly, several previous studies have reported river water quality of Kathmandu Valley [8] [9]. A study undertaken by [9] examined the spatial-temporal variations and factors influencing the management of groundwater along a section of the Bagmati River corridor in the Kathmandu Valley. The results revealed that the biochemical oxygen demand (BOD), total nitrogen (TN) and total phosphorus (TP) concentrations ranged from 8.41 to $29.74 \mathrm{mg} / \mathrm{L}, 6.7$ to $128.96 \mathrm{mg} / \mathrm{L}$ and 0.06 to $1.5 \mathrm{mg} / \mathrm{L}$, respectively in urban areas.

Stable isotopes of water $\left(\delta \mathrm{D}\right.$ and $\left.\delta^{18} \mathrm{O}\right)$ are the important indicators of hydrological and ecological patterns [10]. The main applications of water isotopes are to trace water cycle, determine sources and components of surface water and groundwater flow and separate water sources, identify recharge source [11], identify groundwater mixing and flow path [12] and assess surface and groundwater interrelationship [10].

Groundwater and river water are two interconnected components of one single resource and impacts on either of these components will inevitably affect the quantity or quality of the other [13]. Hydrological interaction between surface water and groundwater can be understood in terms of groundwater recharge and discharge [14]. It is important to know such relationship, however, to our knowledge; there have been no such previous studies in Kathmandu Valley. Few studies on radioactive isotopes such as; ${ }^{36} \mathrm{Cl},(\mathrm{n}=6)$ for determining age of water [15], $\delta^{18} \mathrm{O}$ and $\delta \mathrm{D}$ for determination of shallow groundwater recharge altitudes [11], $\delta^{15} \mathrm{~N}$ and $\delta^{18} \mathrm{O}$ of $\mathrm{NO}_{3}^{-}$for identification of nitrate sources [4] were carried out in Kathmandu Valley. However, the use of stable isotope $\left(\delta^{18} \mathrm{O}\right.$ and $\delta \mathrm{D}$ ) has not been specifically undertaken to understand the interrelationship between river water and groundwater along the river corridor areas and contribution of river water to the groundwater in Kathmandu 
valley. Therefore, this research paper employed stable isotopes $\left(\delta^{18} \mathrm{O}\right.$ and $\left.\delta \mathrm{D}\right), \mathrm{Na}^{+}$and $\mathrm{Cl}^{-}$ions and other selected physico-chemical parameters for the monthly analysis of river waters and shallow groundwater at the river corridors for 2 years with twin objectives to 1 ) assess the anthropogenic influence on the physico-chemical water quality of rivers and shallow groundwater and 2) assess the contribution of river waters to the shallow groundwater.

\section{Materials and Methods}

\subsection{Study Area}

The study area consisted of Bagmati and Bishnumati River corridors of the Kathmandu Valley. The valley is a bowl-shaped intramontane basin located in the central Nepal. The valley covers an area of about $665 \mathrm{~km}^{2}$ which is surrounded by mountain ranges with elevations up to $2800 \mathrm{~m}$ above mean sea level [3]. Kathmandu basin was formed by uplift of the surrounding mountain ranges and was filled by Mid-Pliocene to Holocene fluvio-lacustrine deposits that overlay Precambrian to Devonian metamorphic basement rocks [15] [16]. The mineral composition of the basin is dominated by quartz, K-feldspar, plagioclase and mica with minor chlorite and calcite [17].

Kathmandu Valley has humid sub-tropical climate, which is largely affected by the monsoon [17]. Average precipitation is about $1755 \mathrm{~mm}$ /year with $80 \%$ of rain falling during the summer monsoon between June and September [3]. Surface hydrology in Kathmandu Valley is governed by the Bagmati River system which originates in the Shivapuri Mountains to the north of the valley and discharges to the south of the watershed. This consists of two main groundwater aquifers, shallow and deep aquifers that are separated by a clay aquitard of up to $200 \mathrm{~m}$ thickness [5] [11]. Based on the hydrogeological similarities, the basin is classified into 3 major groundwater districts: northern, central and southern groundwater district [18]. The underlying deposits of northern groundwater district are composed of unconsolidated, permeable materials consisting of micaceous quartz, sand and gravel. The central groundwater district sediment is dominated with a thick black clay layer; which is overlain by fluvial originated fine to medium sand, silt, intercalated clay and fine gravels. The southern groundwater districts possess thick clay layer however parts of the zone (eastern area of this district) are covered with sand and gravel [3].

Bagmati River is an important tributary of the Ganges and has catchment area of $3710 \mathrm{~km}^{2}$ in Nepal. The river has religious and cultural significance which in fact is known as Bagmati Civilization. Bagmati River corridor is the principal resource base of municipal water in the valley, which constitutes water supply to almost $92 \%$ in wet season and $60 \%$ in the dry season. Main sources of water in Bagmati River are rainfall and natural springs. The recorded discharge at Jorpati during wet season is $3.44 \mathrm{~m}^{3} / \mathrm{sec}$ [9].

Bishnumati River, one of the tributaries of the Bagmati River, is also part of the Bagamati Civilization. The river flows between the altitudes of $2481 \mathrm{~m}$ (the origin in the Shivapuri hills) and $1289 \mathrm{~m}$ (confluence with the Bagmati River at Teku). The recorded mean monthly flow of this river at Teku is $0.72 \mathrm{~m}^{3} / \mathrm{sec}$ in March (minimum) and $16.62 \mathrm{~m}^{3} / \mathrm{sec}$ in August (maximum) [8].

\subsection{Sampling and Analysis}

A monitoring network was designed along the Bagmati and Bishnumati River corridors for two years (Figure 1). Three river water samples: R1, R2 and R3 were collected from three different sections (approximately $500 \mathrm{~m}$ apart) along the Bagmati River (at Jorpati reach). Three groundwater samples G1, G2 and G3 were collected from the adjacent shallow tube wells along this river. Similarly, three river water samples: R4, R5 and R6 were collected from Bishnumati River (at Manamaiju reach). Four groundwater samples: G4, G5, G6 and G7 were collected from the surrounding tube wells along this river (Table 1). Water samples from each source were collected monthly from May 2012 to June 2014.

The water samples collected in polyethylene bottles $(250 \mathrm{~mL})$ were rinsed 3 times with the sample water and kept immediately in an ice box. The global positioning system (GPS) was recorded for all the sampling locations.

Some of the physico-chemical parameters of the water samples were measured following standard methods and instruments as listed in the Table 2. Stable isotope analysis were performed using water equilibration system (Sercon, WES) and isotope mass spectrometer (Sercon, Hydra 20 - 20) in the laboratory of the Interdisciplinary 


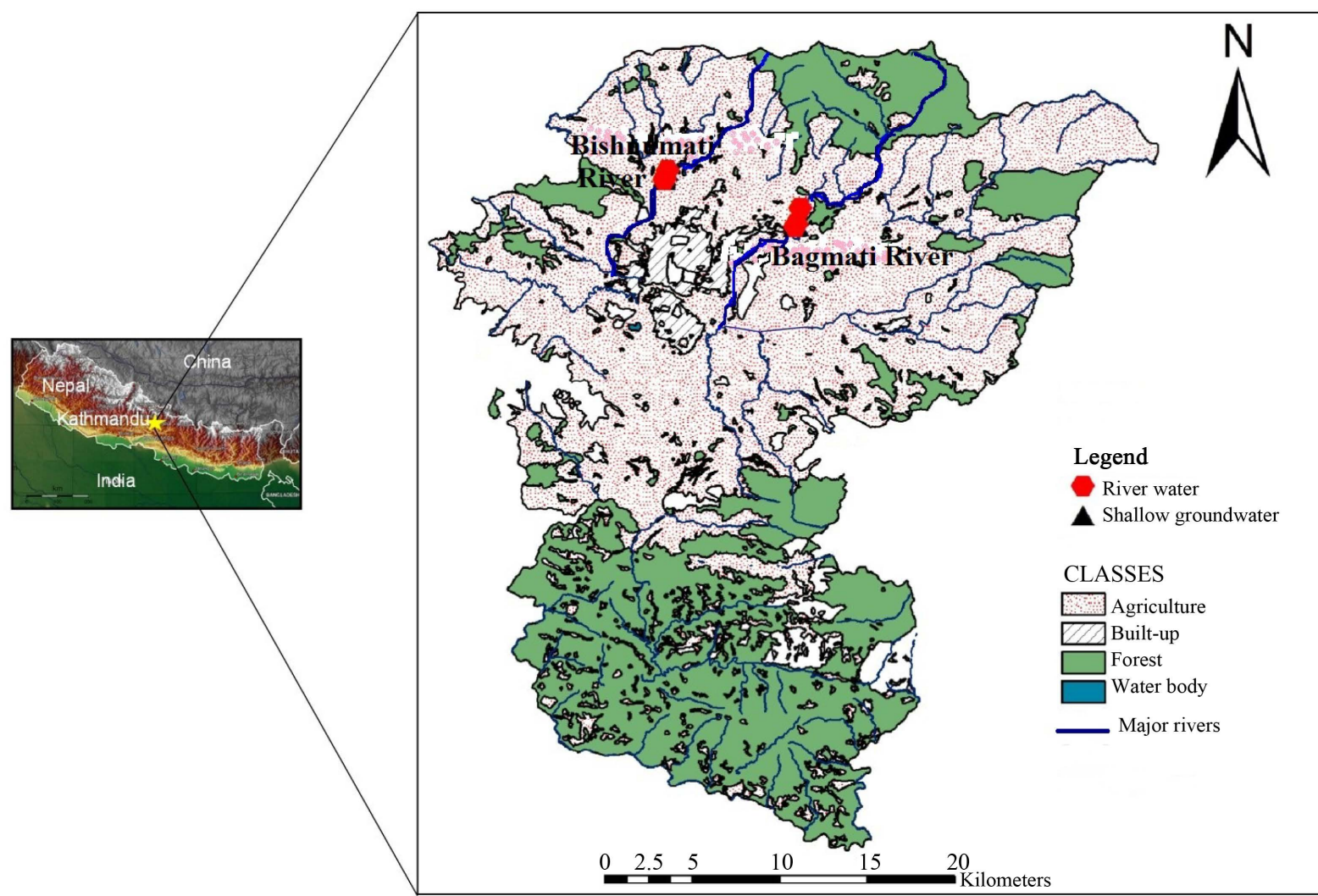

Figure 1. Study area with sampling points.

Table 1. Information on water sampling location.

\begin{tabular}{|c|c|c|c|c|}
\hline Sample ID & Latitude & Longitude & Elevation (m) & Temporal sampling \\
\hline \multicolumn{5}{|c|}{ Shallow groundwater from Jorpati reach } \\
\hline SG1 & $27^{\circ} 43^{\prime} 25.7^{\prime \prime}$ & $85^{\circ} 22^{\prime} 56^{\prime \prime}$ & 1340 & \\
\hline SG2 & $27^{\circ} 43^{\prime} 19.4^{\prime \prime}$ & $85^{\circ} 22^{\prime} 54.6^{\prime \prime}$ & 1336 & Monthly \\
\hline SG3 & $27^{\circ} 43^{\prime} 20.9^{\prime \prime}$ & $85^{\circ} 23^{\prime} 0.8^{\prime \prime}$ & 1310 & \\
\hline \multicolumn{5}{|c|}{ Bagmati River water samples } \\
\hline $\mathrm{R} 1$ & $27^{\circ} 43^{\prime} 55^{\prime \prime}$ & $85^{\circ} 23^{\prime} 5.5^{\prime \prime}$ & 1322 & \\
\hline $\mathrm{R} 2$ & $27^{\circ} 43^{\prime} 25.4^{\prime \prime}$ & $85^{\circ} 22^{\prime} 58^{\prime \prime}$ & 1326 & Monthly \\
\hline R3 & $27^{\circ} 43^{\prime} 19.1^{\prime \prime}$ & $85^{\circ} 22^{\prime} 56.1 "$ & 1342 & \\
\hline \multicolumn{5}{|c|}{ Shallow groundwater from Manamaiju reach } \\
\hline SG4 & $27^{\circ} 45^{\prime} 4.1^{\prime \prime}$ & $85^{\circ} 18^{\prime} 59.3^{\prime \prime}$ & 1305 & \\
\hline SG5 & $27^{\circ} 44^{\prime} 50.6^{\prime \prime}$ & $85^{\circ} 18 ' 52.9^{\prime \prime}$ & 1325 & Monthly \\
\hline SG6 & $27^{\circ} 44^{\prime} 55.8^{\prime \prime}$ & $85^{\circ} 18^{\prime} 54.9^{\prime \prime}$ & 1292 & \\
\hline SG7 & $27^{\circ} 44^{\prime} 46.2^{\prime \prime}$ & $85^{\circ} 18^{\prime} 53.6^{\prime \prime}$ & 1313 & \\
\hline \multicolumn{5}{|c|}{ Bishnumati River water samples } \\
\hline $\mathrm{R} 4$ & $27^{\circ} 45^{\prime} 3.9^{\prime \prime}$ & $85^{\circ} 18^{\prime} 59.5^{\prime \prime}$ & 1302 & \\
\hline R5 & $27^{\circ} 44^{\prime} 50.6^{\prime \prime}$ & $85^{\circ} 18^{\prime} 54.9^{\prime \prime}$ & 1315 & Monthly \\
\hline R6 & $27^{\circ} 44^{\prime} 46.1^{\prime \prime}$ & $85^{\circ} 18^{\prime} 54.1^{\prime \prime}$ & 1314 & \\
\hline
\end{tabular}

Note: SG—Shallow groundwater, R—River water. 
Table 2. Test parameters, methods of analysis and instruments used.

\begin{tabular}{|c|c|c|c|}
\hline Parameters & Unit & Methods of analysis & Instrument/Kit \\
\hline \multicolumn{4}{|l|}{ Physicochemical } \\
\hline $\mathrm{pH}$ & - & pH meter & \\
\hline Electrical conductivity (EC) & $\mu \mathrm{S} / \mathrm{cm}$ & Conductivity meter & $\begin{array}{c}\text { Hanna Combo Tester, HI } \\
98129\end{array}$ \\
\hline Salinity & $\mathrm{mg} / \mathrm{L}$ & & \\
\hline Dissolved Oxygen (DO) & $\mathrm{mg} / \mathrm{L}$ & DO meter & DO meter, ID-100 \\
\hline $\mathrm{NH}_{4}-\mathrm{N}, \mathrm{NO}_{3}-\mathrm{N}, \mathrm{NO}_{2}-\mathrm{N}, \mathrm{PO}_{4}, \mathrm{COD}, \mathrm{Fe}$ & $\mathrm{mg} / \mathrm{L}$ & $\begin{array}{l}\text { Water test kit and Digital Water } \\
\text { Analyzer }\end{array}$ & $\begin{array}{c}\text { Pack Test by } \\
\text { Kyoritsu Chemical-Check } \\
\text { Lab; Corp. Japan, Digital } \\
\text { Water Analyzer (Kyoritsu } \\
\text { Water Analyzer, } \\
\text { DPM-MT). Ammonia } \\
\text { parameter was measured in } \\
\text { UV-VIS Spectrophotometer } \\
\text { (Shimadzu, UYmini-1240) }\end{array}$ \\
\hline $\mathrm{Na}^{+}$ & $\mathrm{mg} / \mathrm{L}$ & AAS Emission & Sercon WES \\
\hline $\mathrm{Cl}^{-}$ & $\mathrm{mg} / \mathrm{L}$ & Argentometric method & $\begin{array}{l}\text { Isotope mass spectrometer } \\
\text { (Sercon, Hydra 20-20) }\end{array}$ \\
\hline \multicolumn{4}{|c|}{ Stable isotope analysis } \\
\hline$\delta^{18} \mathrm{O}, \delta \mathrm{D}$ & per mill (\%o) units & $\begin{array}{l}\text { Water equilibrium system and } \\
\text { isotope mass spectrometer }\end{array}$ & $\begin{array}{l}\text { Sercon, WES and Sercon, } \\
\text { Hydra } 20 \text { - } 20\end{array}$ \\
\hline
\end{tabular}

Centre for River Basin Environment (ICRE), University of Yamanashi, Japan. The analyses were standardized with the international references Vienna Standard Mean Ocean Water (V-SMOW). For $\delta^{18} \mathrm{O}, 1 \mathrm{~mL}$ of each standard and samples were flushed for $\mathrm{CO}_{2}$, then left to equilibrate at $35^{\circ} \mathrm{C}$ on the hot block in the WES for 8 hours before being analyzed. For $\delta \mathrm{D}, 1 \mathrm{~mL}$ of each standard and samples were transferred into individual exetainers containing platinum bead and flushed by $\mathrm{H}_{2}$. The samples were then left to equilibrate in a hot block WES for 3 hours at $35^{\circ} \mathrm{C}$ analysis.

According to standard conventions, all isotopic compositions are given in per mill (\%o) units and $\delta$ notation relative to the V-SMOW standard [19].

$$
\delta \mathrm{D} \text { or }{ }^{18} \mathrm{O}=\frac{R_{\text {sample }}-R_{\mathrm{V}-\mathrm{SMOW}}}{R_{\mathrm{V} \text {-SMOW }}} \times 1000 \%
$$

where $R$ indicates the ration of ${ }^{2} \mathrm{H} /{ }^{1} \mathrm{H}$ or ${ }^{18} \mathrm{O} /{ }^{16} \mathrm{O}$. Analytical uncertainties were $\pm 0.1 \%$ for $\delta^{18} \mathrm{O}$, and $\pm 1 \%$ o for $\delta \mathrm{D}$.

\section{Results and Discussion}

\subsection{Groundwater and River Water Chemistry}

\subsubsection{Groundwater Chemistry}

A summary of the mean physicochemical parameters of the monthly sampling of the 2 years is presented in Table 3 .

The $\mathrm{pH}$ of shallow groundwater was slightly acidic which ranged from 6 - 7.0. Electrical conductivity (EC) was highest $(540 \mu \mathrm{S} / \mathrm{cm})$ in location SG5, water sample collected from Bishnumati River corridor. EC of water is due to the presence of dissolved ionic substances such as metallic ions, organic matters, and ammonium [20]. Dissolved Oxygen (DO) of shallow groundwater ranged from $1.5 \mathrm{mg} / \mathrm{L}$ to $6.0 \mathrm{mg} / \mathrm{L}$. A DO level greater than 2 $\mathrm{mg} / \mathrm{L}$ is required in order to prevent anaerobic conditions that can cause bad odors [21]. The maximum limit for COD for most industrial uses and for environmental sustainability is $8 \mathrm{mg} / \mathrm{L} \mathrm{[21].} \mathrm{The} \mathrm{shallow} \mathrm{groundwater} \mathrm{lo-}$ cations along the Bagmati and Bishnumati River corridors showed that the water quality exceeded the permissible limits for $\mathrm{NH}_{4}^{+}-\mathrm{N}$ and Fe as prescribed by [22] drinking water quality standards; guideline levels for $\mathrm{NH}_{4}^{+}$- 
$\mathrm{N}$ as $\mathrm{NH}_{3}=1.5 \mathrm{mg} / \mathrm{L}$ and $\mathrm{Fe}=0.3 \mathrm{mg} / \mathrm{L}$ (Table 4). Generally, the $\mathrm{NH}_{4}^{+}-\mathrm{N}$ contamination arises from human activities like waste disposal, fertilizer use, contaminated land and wastewater discharge. Also, the $\mathrm{NH}_{4}^{+}-\mathrm{N}$ concentration is produced naturally by mineralization of organic matter and sorption of metal oxide (i.e., Fe and $\mathrm{Mn})$. The anthropogenic sources include waste disposal, fertilizer use, contaminated land and wastewater discharge [23]-[25]. Similar result was identified by [26] which reported that the mean $\mathrm{NH}_{4}^{+}-\mathrm{N}$ concentration in deep and shallow groundwater of Kathmandu Valley were 23.3 and $5.3 \mathrm{mg} / \mathrm{L}$ respectively.

Table 3. Summary of physico-chemical parameters of shallow groundwater and river water.

\begin{tabular}{|c|c|c|c|c|c|c|c|c|c|c|c|}
\hline ID & $\mathrm{pH}$ & $\begin{array}{c}\text { EC } \\
(\mu \mathrm{S} / \mathrm{cm})\end{array}$ & $\begin{array}{l}\text { Salinity } \\
\text { (mg/L) }\end{array}$ & $\begin{array}{c}\mathrm{DO} \\
(\mathrm{mg} / \mathrm{L})\end{array}$ & $\begin{array}{l}\mathrm{NH}_{4}^{+}-\mathrm{N} \\
(\mathrm{mg} / \mathrm{L})\end{array}$ & $\begin{array}{l}\mathrm{NO}_{3}-\mathrm{N} \\
(\mathrm{mg} / \mathrm{L})\end{array}$ & $\begin{array}{c}\text { COD } \\
(\mathrm{mg} / \mathrm{L})\end{array}$ & $\begin{array}{c}\mathrm{PO}_{4} \\
(\mathrm{mg} / \mathrm{L})\end{array}$ & $\begin{array}{c}\mathrm{Fe} \\
(\mathrm{mg} / \mathrm{L})\end{array}$ & $\begin{array}{c}\mathrm{Cl}^{-} \\
(\mathrm{mg} / \mathrm{L})\end{array}$ & $\begin{array}{c}\mathrm{Na}^{+} \\
(\mathrm{mg} / \mathrm{L})\end{array}$ \\
\hline \multicolumn{12}{|c|}{ Shallow groundwater along Bagmati River corridor } \\
\hline SG1 & 6.0 & 256 & 127 & 1.7 & 1.0 & 0.2 & 4.5 & 0.8 & 0.6 & 12.3 & 15.7 \\
\hline SG2 & 6.3 & 263 & 130 & 2.6 & 2.0 & 0.1 & 5.3 & 0.8 & 0.9 & 12.5 & 17 \\
\hline SG3 & 6.0 & 283 & 140 & 1.5 & 0.6 & 1.4 & 5.8 & 0.7 & 2.5 & 15.8 & 19 \\
\hline \multicolumn{12}{|c|}{ Shallow groundwater along Bishnumati River corridor } \\
\hline SG4 & 7.0 & 225 & 114 & 4.7 & 1.8 & 0.6 & 4.6 & 2.5 & 0.3 & 4.0 & 16 \\
\hline SG5 & 6.3 & 540 & 270 & 1.5 & 1.4 & 0.7 & 4.6 & 0.6 & 1.7 & 20 & 17.7 \\
\hline SG6 & 6.3 & 440 & 214 & 2.0 & 1.8 & 0.5 & 6.0 & 1.4 & 2.0 & 14.3 & 20.3 \\
\hline SG7 & 6.3 & 510 & 255 & 2.0 & 1.6 & 0.2 & 5.0 & 1.2 & 0.8 & 21 & 20 \\
\hline \multicolumn{12}{|c|}{ Bagmati River water samples } \\
\hline $\mathrm{R} 1$ & 7.0 & 123 & 61 & 5.5 & 1.0 & 0.4 & 6.5 & 0.3 & 0.3 & 6.3 & 10.6 \\
\hline $\mathrm{R} 2$ & 7.0 & 132 & 67 & 6.2 & 1.0 & 0.5 & 7.5 & 0.4 & 0.2 & 7.2 & 11.5 \\
\hline R3 & 7.0 & 135 & 67 & 5.6 & 0.8 & 0.5 & 7.2 & 0.3 & 0.3 & 6.5 & 11 \\
\hline \multicolumn{12}{|c|}{ Bishnumati River water samples } \\
\hline $\mathrm{R} 4$ & 6.5 & 214 & 109 & 3.2 & 2.5 & 0.2 & 8.5 & 0.6 & 0.4 & 9.7 & 15 \\
\hline R5 & 6.7 & 263 & 131 & 2.7 & 4.0 & 0.3 & 9.3 & 0.7 & 0.3 & 16.3 & 19.5 \\
\hline R6 & 6.8 & 293 & 141 & 2.5 & 4.2 & 0.2 & 9.4 & 0.7 & 0.4 & 17.4 & 20 \\
\hline
\end{tabular}

Note: EC: Electrical Conductivity, COD: Chemical Oxygen Demand, DO: Dissolved Oxygen. ${ }^{*}$ Please note that all the parameter values are the mean values of the monthly sampling of the 2 years.

Table 4. Range of physico-chemical parameters of shallow groundwater and river water.

\begin{tabular}{|c|c|c|c|c|c|c|c|c|c|c|}
\hline \multirow{2}{*}{ Parameter } & \multirow{2}{*}{ Unit } & \multicolumn{4}{|c|}{ Shallow groundwater } & \multicolumn{4}{|c|}{ River water } & \multirow{2}{*}{ WHO 2004} \\
\hline & & Ave & Min & Max & SD & Ave & Min & Max & SD & \\
\hline $\mathrm{pH}$ & & 6.3 & 6.0 & 7.0 & 0.3 & 6.8 & 6.5 & 7.0 & 0.2 & $6.5-8.5$ \\
\hline EC & $\mu \mathrm{S} / \mathrm{cm}$ & 360 & 225 & 540 & 132.7 & 193.3 & 123 & 293 & 74.0 & 1500 \\
\hline Salinity & $\mathrm{mg} / \mathrm{L}$ & 179 & 114 & 270 & 66 & 96.0 & 61 & 141 & 35.6 & - \\
\hline DO & $\mathrm{mg} / \mathrm{L}$ & 2.3 & 1.5 & 4.7 & 1.1 & 4.3 & 2.5 & 6.3 & 1.7 & - \\
\hline $\mathrm{NH}_{4}^{+}-\mathrm{N}$ & $\mathrm{mg} / \mathrm{L}$ & 1.5 & 0.6 & 2 & 0.5 & 2.3 & 0.8 & 4.3 & 1.5 & 1.5 as $\mathrm{NH}_{3}$ \\
\hline $\mathrm{NO}_{3}-\mathrm{N}$ & $\mathrm{mg} / \mathrm{L}$ & 0.5 & 0.1 & 1.4 & 0.4 & 0.4 & 0.2 & 0.5 & 0.1 & $\begin{array}{c}50.0 \text { for } \\
\text { total } \\
\text { nitrogen }\end{array}$ \\
\hline COD & $\mathrm{mg} / \mathrm{L}$ & 5.0 & 4.5 & 6.0 & 0.6 & 8.0 & 6.5 & 9.4 & 1.3 & \\
\hline $\mathrm{PO}_{4}$ & $\mathrm{mg} / \mathrm{L}$ & 1.0 & 0.6 & 2.5 & 0.7 & 0.5 & 0.3 & 0.7 & 0.2 & $0.4-5.5$ \\
\hline $\mathrm{Fe}$ & $\mathrm{mg} / \mathrm{L}$ & 1.3 & 0.3 & 2.5 & 0.8 & 0.3 & 0.2 & 0.4 & 0.1 & 0.3 \\
\hline $\mathrm{Cl}^{-}$ & $\mathrm{mg} / \mathrm{L}$ & 14.3 & 4.0 & 21 & 5.7 & 10.6 & 6.3 & 17.4 & 5.0 & 250 \\
\hline $\mathrm{Na}^{+}$ & $\mathrm{mg} / \mathrm{L}$ & 18 & 15.7 & 20.3 & 2.0 & 14.6 & 10.6 & 20.0 & 4.3 & - \\
\hline
\end{tabular}

Note: Ave: average, Min: minimum, Max: maximum, SD: standard deviation. 


\subsubsection{River Water Chemistry}

As shown in Table 3, DO of river water ranged from 2.5 to $6.3 \mathrm{mg} / \mathrm{L}$. As per Nepal Water Quality Guidelines for Aquaculture, DO levels in water should not drop below $5.0 \mathrm{mg} / \mathrm{L}$, otherwise aquatic life is put under stress. The $\mathrm{NH}_{4}^{+}-\mathrm{N}$ concentrations ranged from 0.8 to $4.0 \mathrm{mg} / \mathrm{L}$. Nitrogen content must be less than $5 \mathrm{mg} / \mathrm{L}$ since higher concentration may affect sensitive plants and may contaminate groundwater [27]. The most common sources of nitrogen are industrial, human pollutions and fertilizers [9]. The $\mathrm{Cl}^{-}$and $\mathrm{Na}^{+}$ions showed the pronounced effects of urbanization especially on the major ion chemistry of the Bishnumati River. The increasing trend of $\mathrm{Cl}^{-}$concentration from upstream to downstream (see Table 3) is because of pollution with anthropogenic activities. Chloride and sodium are major electrolytes in human urine [28] and are concentrated primarily in waste water. Sources of these ions in river and groundwater are related to human activities, effluent from industrial facilities and septic systems, and some agricultural chemicals [29]. The physico-chemical values (Table 3 ) indicated that the shallow groundwater and river water along the Bishnumati River corridor was highly mineralized than Bagmati River.

\subsection{Characteristics of $\mathrm{Na}^{+}$and $\mathrm{Cl}^{-}$}

The sum of $\mathrm{Na}^{+}$and $\mathrm{Cl}^{-}$concentrations of river waters at sampling locations R1, R2 and R3 were nearly similar to the concentrations of shallow groundwater at SG1 during the months November 2012 to May 2013 (Figure 2). Similarly, the concentration was found similar to the concentration at sampling locations SG1, SG2 and SG3 during the months January to May 2014. The sum of $\mathrm{Na}^{+}$and $\mathrm{Cl}^{-}$concentrations of river water was high which reached up to $60 \mathrm{mg} / \mathrm{L}$ during the month of May 2014. However, these ions were found higher in shallow groundwater compared to river water.

Similarly, the $\mathrm{Na}^{+}$and $\mathrm{Cl}^{-}$concentrations of shallow groundwater and river water were similar during several months along the Bishnumati River corridor (Figure 3). The river water collected from Bishnumati River had high $\mathrm{Na}^{+}$and $\mathrm{Cl}^{-}$concentrations. It could be due to the discharge of a large amount of domestic waste water. The banks of the Bishnumati River have become provisional landfill sites. The uncontrolled dumping has severely contaminated the groundwater as well as river water [8].

The similar patterns of sum of $\mathrm{Na}^{+}$and $\mathrm{Cl}^{-}$concentrations in river waters and shallow groundwater collected from Bagmati and Bishnumati River corridors showed that there is possibility of interrelationship between these water sources.

The relationship of $\mathrm{Na}^{+}$and $\mathrm{Cl}^{-}$concentrations is used to identify groundwater origin and sources of the groundwater chemical constituents [30]. The ratio of $\mathrm{Na}^{+} / \mathrm{Cl}^{-}$of river water and shallow groundwater samples

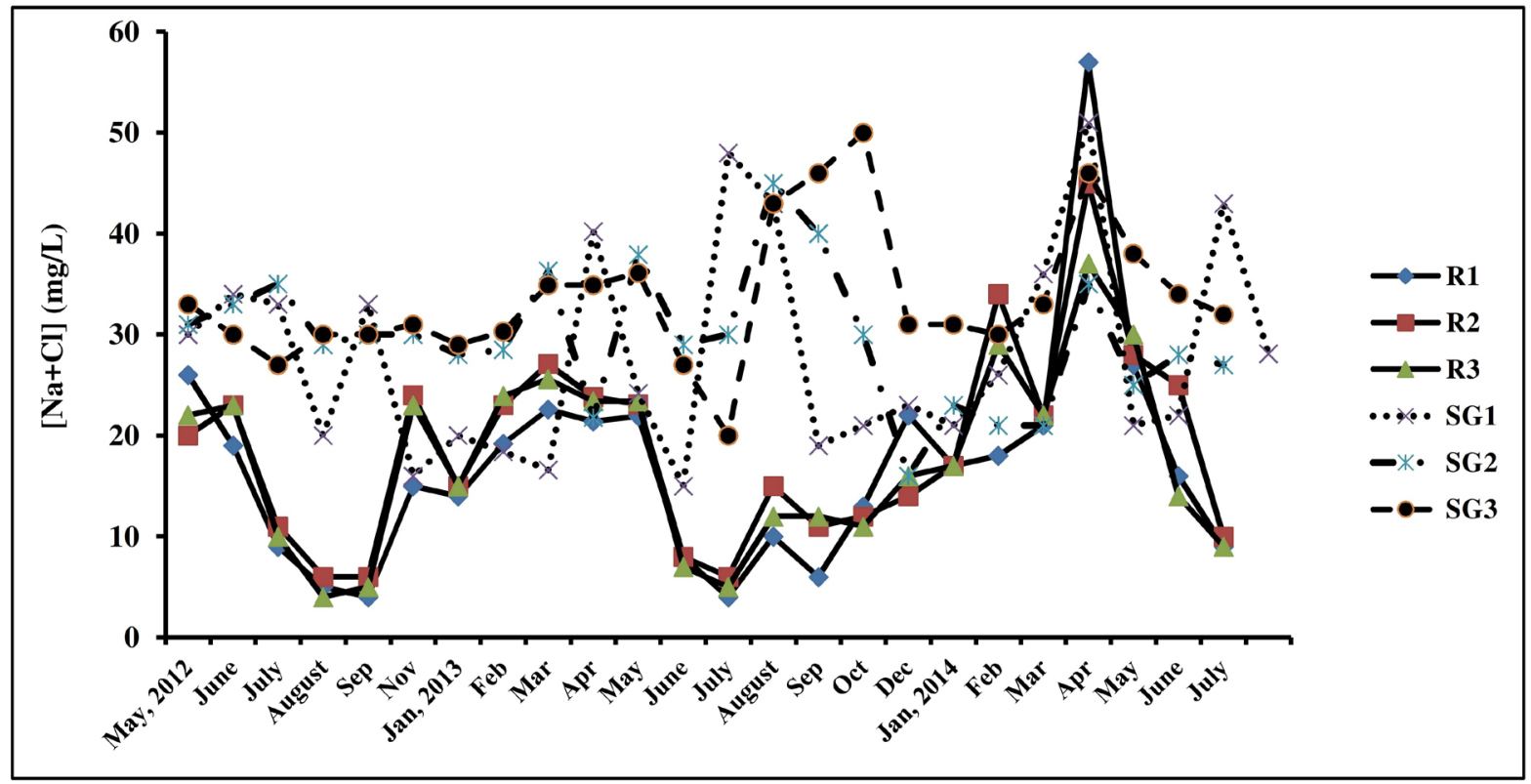

Figure 2. Temporal distribution of sum of $(\mathrm{Na}+\mathrm{Cl})$ concentrations along the Bagmati River corridor. 
were plotted in Figure 4. The ratio of $\mathrm{Na}^{+}$and $\mathrm{Cl}^{-}$nearly followed 1:1 ratio in river water $\left(\mathrm{R}^{2}=0.983\right)$. The natural sources of these ions are rock-water interactions, saline seeps, and minor atmospheric inputs. Other anthropogenic sources include: agricultural chemicals, effluent from private and municipal septic systems, animal waste [31]. However, $\mathrm{Na}^{+}$concentrations were comparatively higher than $\mathrm{Cl}^{-}$concentrations in shallow groundwater. High concentration of $\mathrm{Na}^{+}$irrespective to $\mathrm{Cl}^{-}$concentrations in shallow groundwater probably resulted from rock-water interactions with Na-clays and Na-feldspars present as silt-and sand-size fragments in the soil zone and aquifers [31].

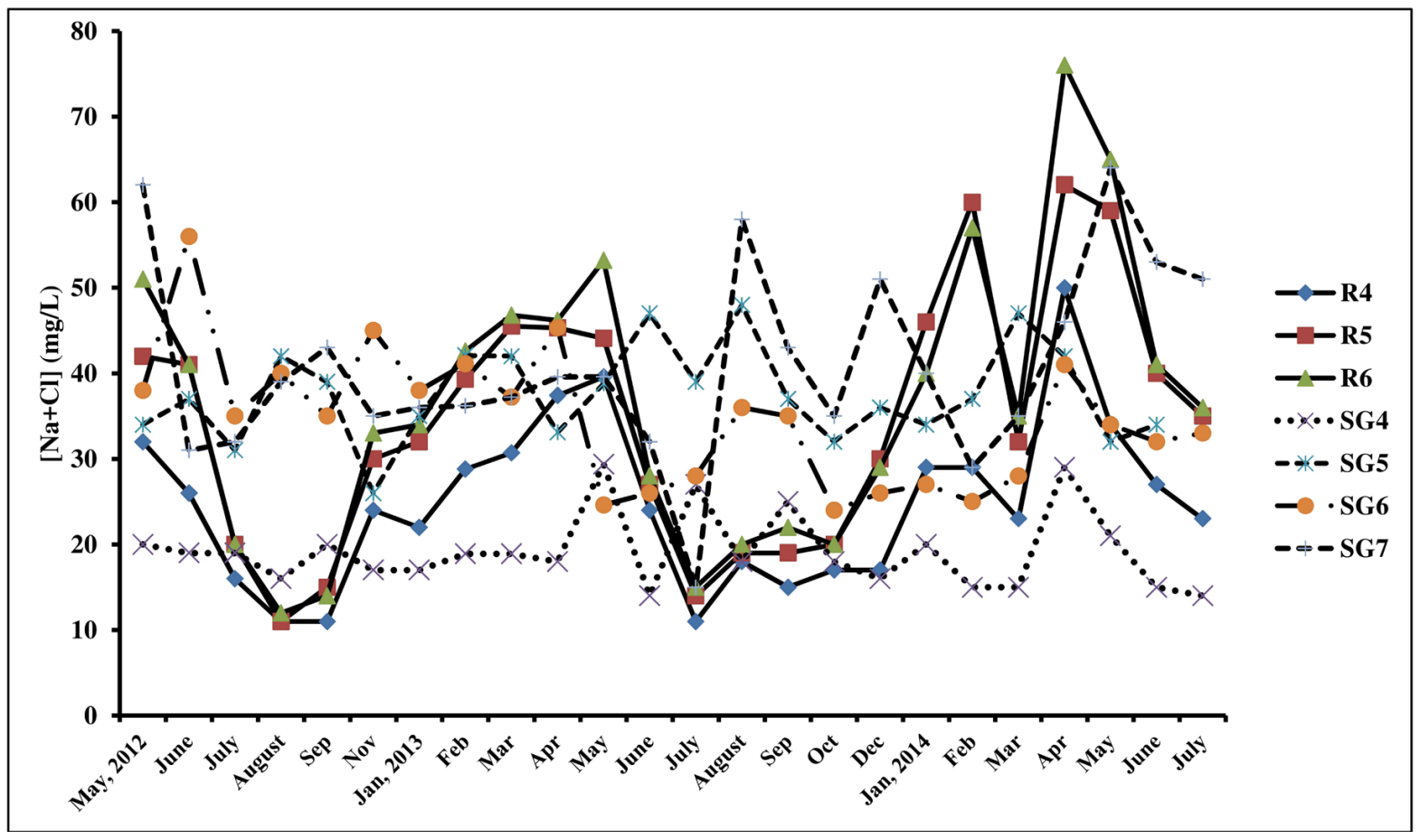

Figure 3. Temporal distribution of sum of $(\mathrm{Na}+\mathrm{Cl})$ concentrations along the Bishnumati River corridor.

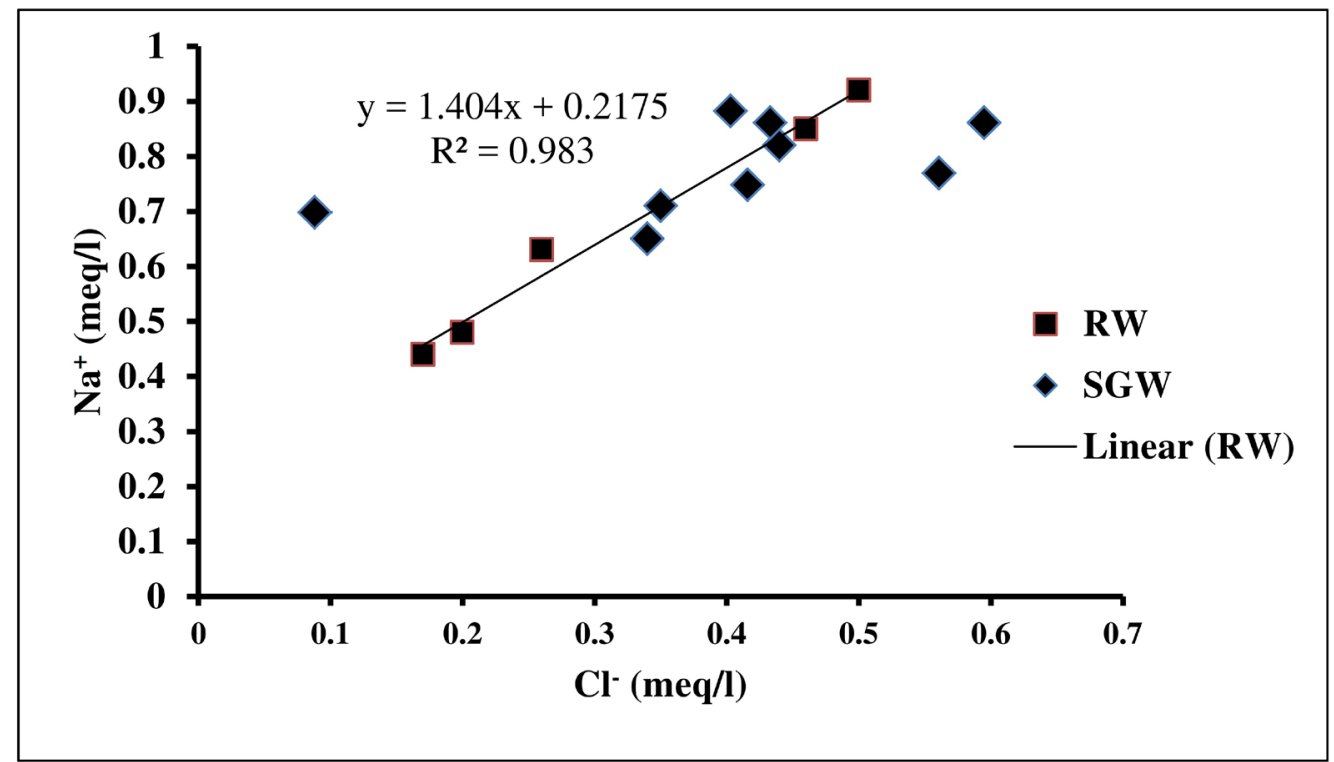

Figure 4. A scatter diagram of $\mathrm{Na}^{+}$and $\mathrm{Cl}^{-}$. River water samples plotted along a line defined by $\mathrm{NaCl}$; while shallow groundwater samples showed elevated $\mathrm{Na}^{+}$concentrations ("SGW-Shallow groundwater; $R W$-River water). 


\subsection{Stable Isotope Composition of Groundwater and River Water}

The mean values of the isotopic composition $\left(\delta^{18} \mathrm{O}\right.$ and $\left.\delta \mathrm{D}\right)$ of shallow groundwater and river water are presented in Table 5. The $\delta^{18} \mathrm{O}$ value of shallow groundwater ranged from $-7.7 \%$ o to $-4.8 \%$; and $\delta \mathrm{D}$ from $-69.8 \%$ o to $-49 \%$. The $\delta^{18} \mathrm{O}$ value of river water ranged from $-7.5 \%$ to $-4.4 \%$ and $\delta \mathrm{D}$ ranged from $-71.3 \%$ o to $-49.6 \%$ o respectively. The isotopically lightest for $\delta^{18} \mathrm{O}$ and $\delta \mathrm{D}$ in sample were $-7.7 \%$ and $-71.3 \%$, and the heaviest were $-4.4 \%$ and $-49 \%$ respectively.

The Global Meteoric Water Line (GMWL) was drawn using the following equation described by [19]

$$
\delta \mathrm{D}=8 \times \delta^{18} \mathrm{O}+10
$$

The Local Meteoric Water Line (LMWL) published for Kathmandu Valley was used which was based on sampling of rain water during pre-monsoon and monsoon seasons [32].

The hydrogen and oxygen isotope values of groundwater and river water were plotted on reported LMWL for Kathmandu valley (Figure 5). The isotopic composition of the shallow groundwater nearby the Bagmati River corridor plots close to the LMWL. It revealed the rainwater as the possible source of this shallow groundwater. While the isotopic compositions of Bagmati River, Bishnumati River and Bishnumati shallow groundwater plotted below the LMWL in the plot, this indicated possible evaporation or mixing line. The main causes of variations in the stable isotope signature of water sources were natural variations in the isotopic composition of rainfall, mixing with pre-existing waters, and evaporation through soil [33] [34]. In addition, isotopic composition of river water and shallow ground water clustered together (see Figure 5) reflected existence of certain degree of interrelationship between river water and groundwater [14].

\subsection{Seasonal Isotopic Variation in Groundwater and River Water}

The Figure 6 and Figure 7 showed the seasonal isotopic compositions of shallow groundwater and river water during dry and wet seasons.

The isotopic compositions were clearly divided into three clusters.

Cluster 1: The isotopic composition of river water and shallow groundwater plotted on or nearby the LMWL.

Cluster 2: The isotopic composition of some of the shallow groundwater samples deviated from LMWL

Cluster 3: The isotopic composition of river water and shallow groundwater deviated from LMWL.

The deviation of isotopic compositions of river water and groundwater from the LMWL revealed water has undergone evaporation with systematic enrichment in stable isotope [29] [35]. In contrast to this, previous studies investigated that none of the Kathmandu Valley rivers showed evidence for evaporation except for minor

Table 5. Average isotopic compositions of shallow groundwate and river water.

\begin{tabular}{cccc}
\hline ID & Average $\boldsymbol{\delta}^{\mathbf{1 8}} \mathbf{O}(\mathbf{\%})$ & Average $\boldsymbol{\delta} \mathbf{D}(\mathbf{( \% )}$ & Remarks \\
\hline SG1 & -6.9 & -50.4 & Shallow groundwater along Bagmati \\
River corridor
\end{tabular}

*Please note that all the parameter values are the mean values of the monthly sampling of the 2 years. 


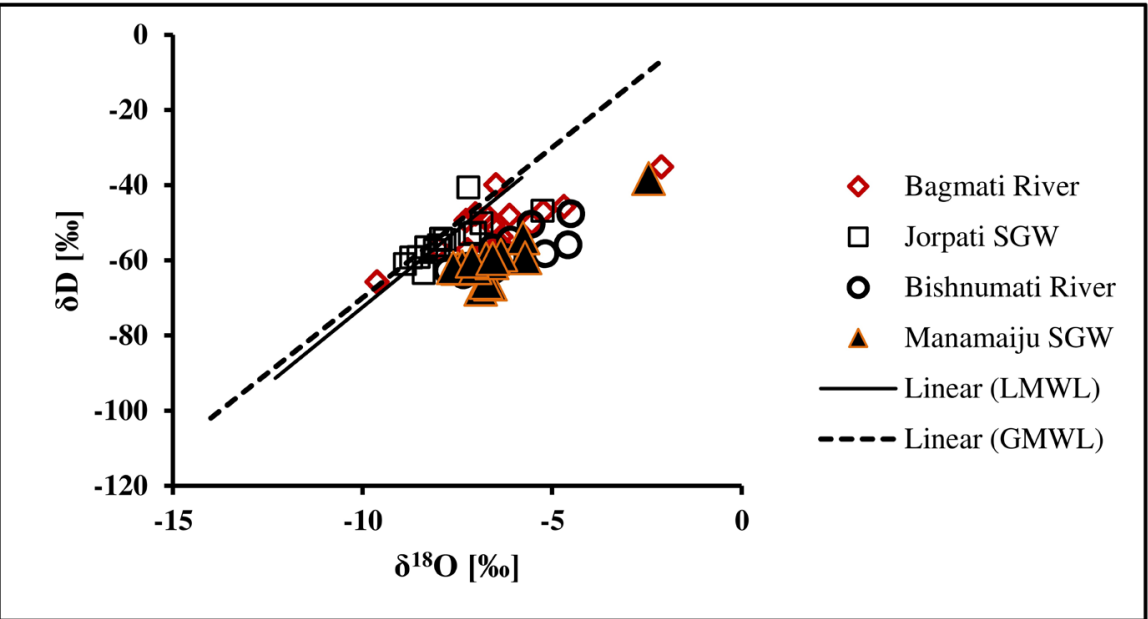

Figure 5. Relationship of $\delta \mathrm{D}$ and $\delta^{18} \mathrm{O}$ of the shallow groundwater and rivers with GMWL and LMWL.

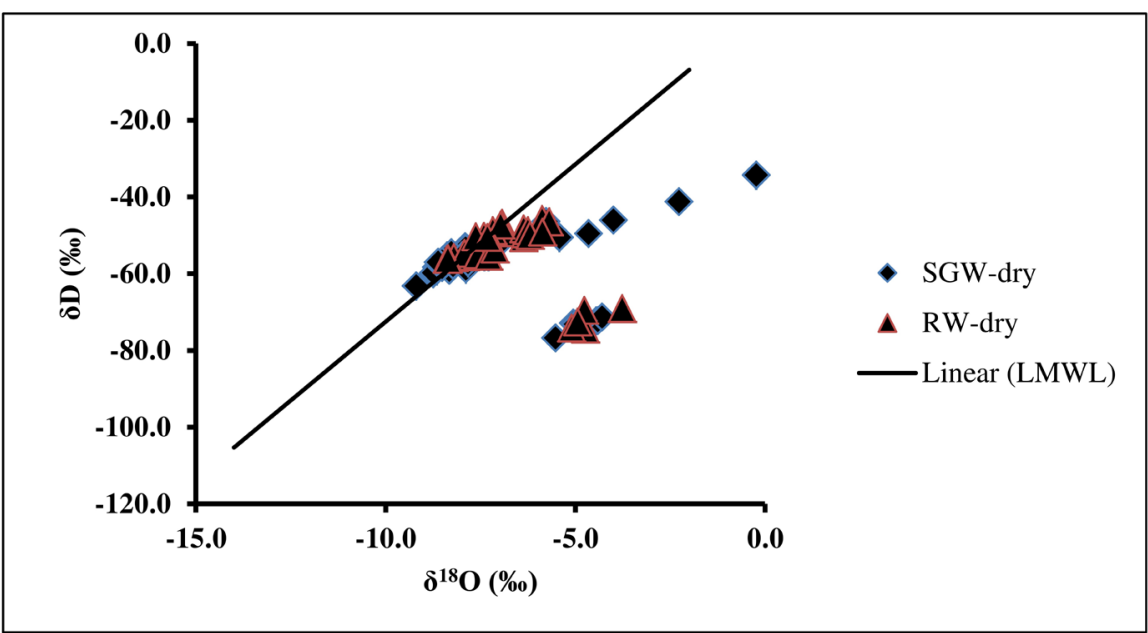

Figure 6. Stable isotopic composition of shallow groundwater and river water during dry season.

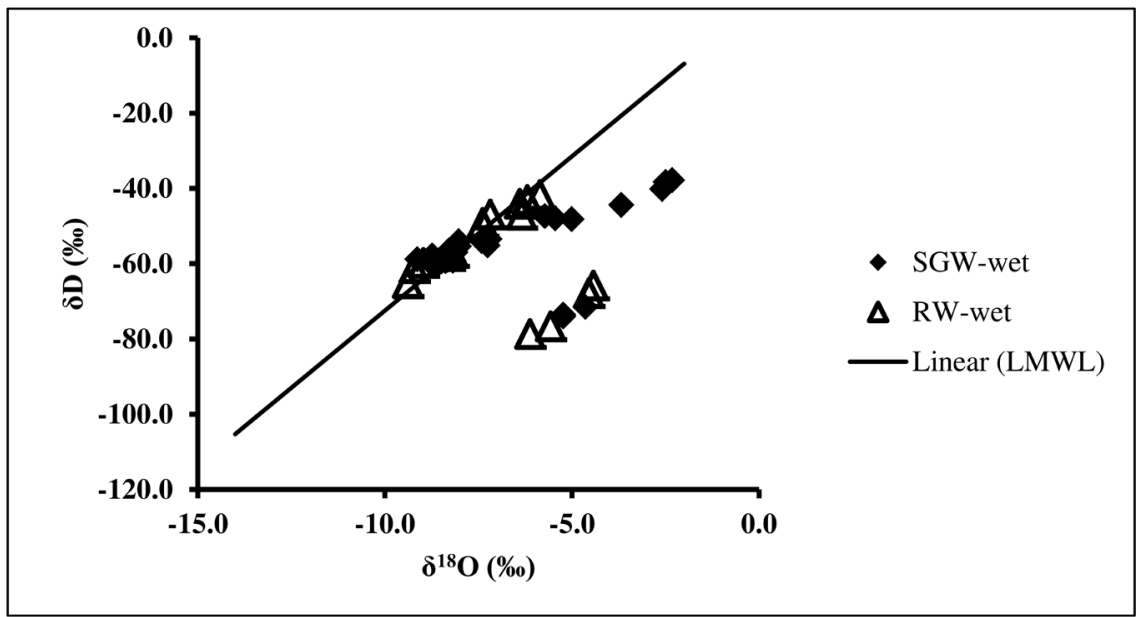

Figure 7. Stable isotopic composition of water during wet season. 
catchments in the valley during monsoon [32] [36]. Such variation in isotope compositions of river water could be expected due to lack of natural river flow, whereas the river discharge in Kathmandu is usually influenced by anthropogenic activities such as discharge of domestic wastewater into river. It revealed that the sampling locations were more or less likely to be mixed with sewer water. Similar results were reported by [31] in which most of the river water samples were plotted along a similar evaporation trend. Also, landfill leachate, septic effluent and animal wastes which have elevated $\delta^{18} \mathrm{O}$ values were also plotted along the evaporation trend. However, such effects could be detected using stable isotope ratios such as, $\delta^{15} \mathrm{~N}, \delta^{13} \mathrm{C}$ and $\delta^{34} \mathrm{~S}$ [37].

Similar pattern was seen in the isotopic composition of wet season of the river water and groundwater (Figure 7).

\subsection{Relationship between $\delta^{18} 0$ and $\mathrm{Cl}^{-}$}

The relationship of chloride $\left(\mathrm{Cl}^{-}\right)$and stable isotope of oxygen $\left(\delta^{18} \mathrm{O}\right)$ in river water and groundwater was plotted in Figure 8. It showed a close range of $\delta^{18} \mathrm{O}$ and $\mathrm{Cl}^{-}$concentrations in shallow groundwater and river water, which indicated the possible hydraulic interaction between river water and shallow groundwater [38].

\subsection{Interrelationship between River Water and Groundwater}

The physicochemical properties and isotopic compositions of the river water and groundwater revealed interrelationship existed between them. In addition, mass balance approach was used to find out the mixing contribution of river water into the shallow groundwater.

\subsubsection{Case 1: Bagmati River Corridor}

To determine the fractional contribution, let us take an example of shallow groundwater SG1 and river water from Bagmati River corridor. The SG1 seemed to be closely connected to the nearest river water as the groundwater had similar trends of stable isotope signatures with the river. The salient features of the isotope and $\mathrm{Cl}^{-}$ concentration of shallow groundwater at SG1 were as follows. During pre monsoon period (April 2013), the $\delta^{18} \mathrm{O}$ and $\delta \mathrm{D}$ of shallow groundwater were $-7.4 \%$ and $-52.9 \%$ respectively. During the monsoon (September 2013), the $\delta^{18} \mathrm{O}$ and $\delta \mathrm{D}$ was found to be depleted (-8.3\%o and $-56.5 \%$ respectively). In the same way, the $\mathrm{Cl}^{-}$ concentration in September 2013, was also diluted to $5 \mathrm{mg} / \mathrm{l} \mathrm{from} 19 \mathrm{mg} / \mathrm{L}$ (in April 2013). That is because the recharge by river water via bank infiltration in September 2013, could be characterized by lower $\mathrm{Cl}^{-}$and relatively depleted $\delta^{18} \mathrm{O}$ and $\delta \mathrm{D}$ signatures.

Assuming that SG1 in September 2013 was a result of mixing original groundwater (GW) and river water (RW), the following equation can be used to assess the fractional contributions of river water to the groundwater [29]:

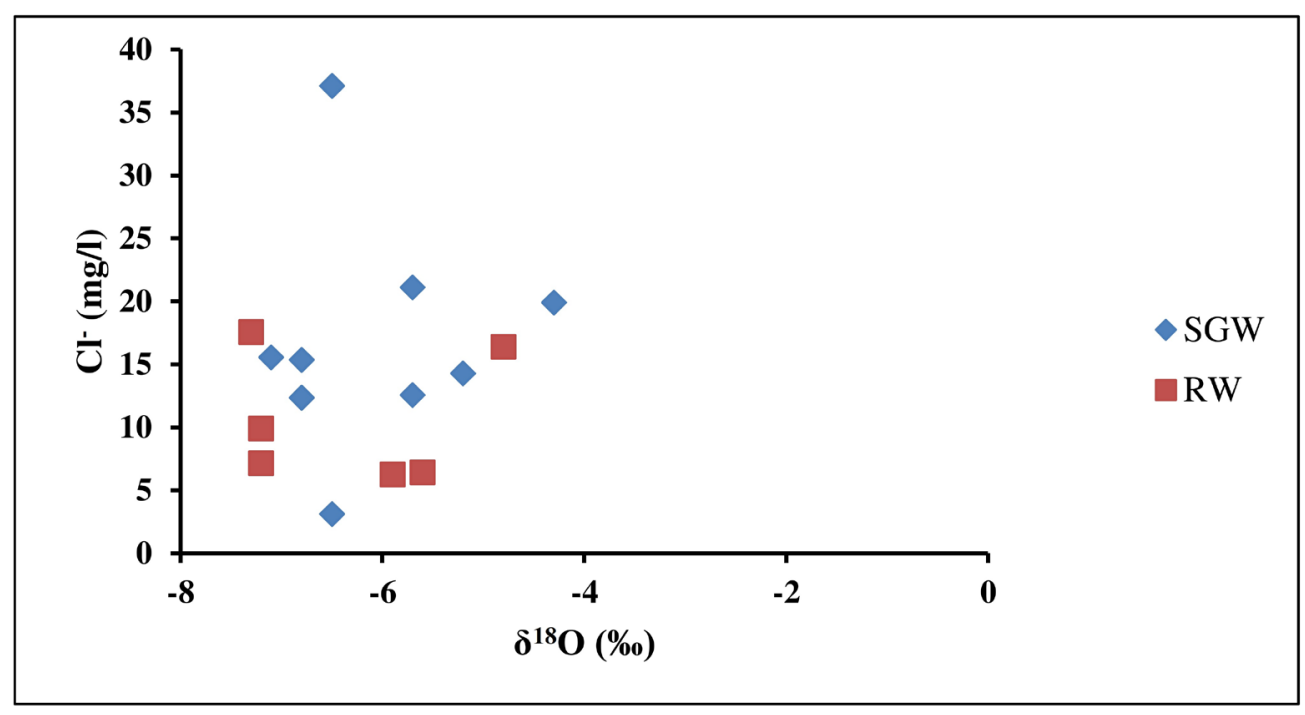

Figure 8. Relationship between $\mathrm{Cl}^{-}$and $\delta^{18} \mathrm{O}$ in groundwater and river water. 


$$
f=\frac{\mathrm{C}_{\mathrm{s}}-\mathrm{C}_{\mathrm{GW}}}{\mathrm{C}_{\mathrm{RW}}-\mathrm{C}_{\mathrm{GW}}} \times 100 \%
$$

where Cs is the $\delta^{18} \mathrm{O}(-8.3 \%)$ or $\delta \mathrm{D}(-56.5 \%)$ of the water sample (location SG1 in September 2013); $\mathrm{C}_{\mathrm{RW}}$ is the $\delta^{18} \mathrm{O}(-9.5 \%)$ or $\delta \mathrm{D}\left(-65.3 \%\right.$ o) of river water (location R1 in September 2013); and $\mathrm{C}_{\mathrm{GW}}$ is the $\delta^{18} \mathrm{O}(-7.4 \%$ ) or $\delta \mathrm{D}(-52.9 \%)$ of shallow groundwater SG1 in April 2013.

The resulting fractional contribution percentages were $30 \%$ and $40 \%$ using $\delta^{18} \mathrm{O}$ and $\delta \mathrm{D}$, respectively. Mixing calculations suggested that the shallow groundwater at SG1 of Bagmati River corridor in September 2013 was composed of approximately 30\% - 40\% Bagmati River water. This result showed that contamination of river water can reach into the groundwater if the river water is severely polluted.

\subsubsection{Case 2: Bishnumati River Corridor}

Similarly, the Equation (1) was used to calcute fractional contribution of Bishnumati River to the shallow groundwater along this corridor. The sampling location SG5 seemed to have similar trends of stable isotope signatures with Bishnumati River was taken into consideration. The salient features of the isotope and hydrochemistry of shallow groundwater at SG5 are as follows. During pre-monsoon period (April 2013), the $\delta^{18} \mathrm{O}$ and $\delta \mathrm{D}$ of shallow groundwater were $-4.4 \%$ and $-72.2 \%$, respectively. During the monsoon (September 2013), the $\delta^{18} \mathrm{O}$ and $\delta \mathrm{D}$ was found to be depleted ( $-5.1 \%$ and $-74.4 \%$ respectively).

Using the equation to assess the fractional contributions of river water to the shallow groundwater SG5 in September 2013:

Where Cs is the $\delta^{18} \mathrm{O}\left(-5.1 \%\right.$ ) or $\delta \mathrm{D}\left(-74.4 \%\right.$ ) of the water sample (location SG5 in September 2013); $\mathrm{C}_{\mathrm{RW}}$ is the $\delta^{18} \mathrm{O}(-5.9 \%)$ or $\delta \mathrm{D}(-77.1 \%)$ of river water (location $\mathrm{R} 4$ in September 2013); and $\mathrm{C}_{\mathrm{GW}}$ is the $\delta^{18} \mathrm{O}(-4.4 \%)$ or $\delta \mathrm{D}(-72.2 \%)$ of shallow groundwater SG5 in April 2013.

The resulting fractional contribution percentages were $45 \%$ and $47 \%$ using $\delta^{18} \mathrm{O}$ and $\delta \mathrm{D}$, respectively. Mixing calculations suggested that SG5 of Bishnumati River corridor in September 2013 was composed of approximately $45 \%$ - $50 \%$ river water.

\section{Conclusions}

The Bagmati and Bishnumati River corridors are facing environmental pressures, mainly from anthropogenic influences. The major findings of the study were:

1) The shallow groundwater along the Bagmati and Bishnumati River corridor were found to be contaminated with ammonium and iron. The physico-chemical values revealed that the shallow groundwater and river water along the Bishnumati River corridor were heavily mineralized compared to Bagmati River corridor due to direct discharge of sewage wastes into this river. The uncontrolled dumping severely contaminated the groundwater as well as river water. The similar temporal trend of $\mathrm{Na}^{+}$and $\mathrm{Cl}^{-}$concentrations of shallow groundwater and river water indicated the common source of origin of these ions in both groundwater and river. In addition, it revealed the possible interrelationship between these water sources.

2) The isotope compositions of river waters and shallow ground water clustered together reflected existence of possible interrelationship between them. The plot of seasonal isotopic compositions of water sources divided them into 3 clusters. Some of the isotopic compositions of water sources diverted from the LMWL which revealed that water has undergone evaporation with systematic enrichment in stable isotope. In addition, such variation in river water could be expected due to lack of natural river flow, which meant that rivers in our study were highly influenced by anthropogenic activities.

3) Fractional contributions of the river water to the groundwater were calculated based on isotopic data using mass balance approach. The shallow groundwater along the Bagmati River corridor (SG1) in September 2013 was composed of approximately 30\% - 40\% Bagmati River water. Similarly, SG5 of Bishnumati River corridor in September 2013 was composed of approximately 45\% - 50\% river water. This result indicated that high portion of river water mixed-up with adjoining shallow groundwater along the river corridors. Further, the mix-up of the river water with groundwater can be harmful when rivers are polluted.

\section{Acknowledgements}

We are thankful to Interdisciplinary Centre for River Basin Environment (ICRE), University of Yamanashi, Ja- 
pan for their support and encouragement especially for the isotopic analysis. We also acknowledge Sarad Pathak from CREEW for his assistance during water sampling and analysis.

\section{References}

[1] Jha, M.G., Khadka, M.S., Shrestha, M.P., Regmi, S., Bauld, J. and Jacobson, G. (1997) The Assessment of Groundwater Pollution in Kathmandu Valley, Nepal. A Report on Joint Nepal-Australia Project 1995-1996, Australian Geological Survey Organization, Canberra, 64.

[2] Khatiwada, N.R., Takizawa, S., Tran, T.V.N. and Inoue, M. (2002) Groundwater Contamination Assessment for Sustainable Water Supply in Kathmandu Valley, Nepal. Water Science and Technology, 46, 147-154.

[3] Pandey, V.P., Chapagain, S.K. and Kazama, F. (2010) Evaluation of Groundwater Environment of Kathmandu Valley. Environment Earth Sciences, 60, 1329-1342. http://dx.doi.org/10.1007/s12665-009-0263-6

[4] Shrestha, S., Nakamura, T., Yoneyyama, Y., Shrestha, S. and Kazama, F. (2013) Identification of Nitrate Sources in Rainwate of Kathmandu Valley: A Chemical and Stable Isotopic Approach. Journal of Water and Environment Technology, 11, 377-389. http://dx.doi.org/10.2965/jwet.2013.377

[5] Warner, N.R., Levy, J., Harpp, K. and Farruggia, F. (2008) Drinking Water Quality in Nepal's Kathmandu Valley: A Survey and Assessment of Selected Controlling Site Characteristics. Hydrogeology Journal, 16, 321-334. http://dx.doi.org/10.1007/s10040-007-0238-1

[6] Pathak, D.R., Hiratsuka, A., Yamashiki, Y. (2011) Influence of Anthropogenic Activities and Seasonal Variation on Groundwater Quality of Kathmandu Valley Using Multivariate Statistical Analysis. Proceedings of the Symposium on Water Quality: Current Trends and Expected Climate Change Impacts, IUGG2011 in Melbourne, Australia, July 2011 (IAHS Publ. 348, 2011).

[7] Nakamura, T., Osaka, K., Chapagain, S.K., Nishida, K. and Kazama, F. (2010) Identification of Nitrate Sources in Shallow Groundwater of Kathmandu Valley, Nepal Using Nitrate Nitrogen and Oxygen Isotope. Paper Presented on Japan Geosciences Union Meeting 2010, May 2010, Chiba.

[8] Devkota, D.C. and Watanabe, K. (2005) Impact of Solid Waste on Water Quality of Bishnumati River and Surrounding Areas in Kathmandu, Nepal. Journal of Nepal Geological Society, 31, 19-24.

[9] Kannel, P.R., Lee, S. and Lee, Y.S. (2008) Assessment of Spatial-Temporal Patterns of Surface and Ground Water Qualities and Factors Influencing Management Strategy of Groundwater System in an Urban River Corridor of Nepal. Journal of Environmental Management, 86, 595-604.

[10] Weyhenmeyer, C.E., Burns, S.J. and Waber, H.N. (2002) Isotope Study of Moisture Sources, Recharge Areas, and Goundwater Flow Paths within the Eastern Batinah Coastal Plain, Sultanate of Oman. Water Resources Research, 38, 1184-1206. http://dx.doi.org/10.1029/2000WR000149

[11] Nakamura, T., Chapagain, S.K., Pandey, V.P., Osada, K., Nishida, K., Malla, S.S. and Kazama, F. (2012) Shallow Groundwater Recharge Altitudes in the Kathmandu Valley. In: Shrestha, S., Pradhananaga, D. and Pandey, V.P., Eds., Kathmandu Valley Groundwater Outlook, Asian Institute of Technology (AIT), The Small Earth Nepal (SEN), Center of Research for Environment Energy and Water (CREEW), International Research Center for River Basin Environment, University of Yamanashi (ICRE-UY), Kofu, 39-45.

[12] Idowu, O.A. (2007) Hydrogeological Processes of Interaction between Surface Water and Groundwater-A Review. ASSET Series, 6, 172-190.

[13] Winter, T.C. (1999) Relation of Streams, Lakes and Wetlands to Groundwater Flow Systems. Hydrogeology Journal, 7, 28-45. http://dx.doi.org/10.1007/s100400050178

[14] Song, X.F., Liu, X.C., Xia, J., Yu, J.J. and Tang, C.Y. (2006) A Study of Interaction between Surface Water and Groundwater Using Environmental Isotope in Huaisha River Basin. Science in China Series D: Earth Sciences, 49, 1299-1310. http://dx.doi.org/10.1007/s11430-006-1299-z

[15] Cresswell, R.G., Bauld, J., Jacobson, G., Khadka, M.S., Jha, M.G., Shrestha, M.P. and Regmi, S. (2001) A First Estimate of Ground Water Ages for the Deep Aquifer of the Kathmandu Basin, Nepal, Using the Radioisotope Chlorine-36. Ground Water, 39, 449-457. http://dx.doi.org/10.1111/j.1745-6584.2001.tb02329.x

[16] Gurung, J.K., Ishiga, H., Khadka, M.S. and Shrestha, N.R. (2007) The Geochemical Study of Fluvio-Lacustrine Aquifers in the Kathmandu Basin (Nepal) and the Implications for the Mobilization of Arsenic. Environmental Geology, 52, 503-517. http://dx.doi.org/10.1007/s00254-006-0483-y

[17] Paudel, M.R., Kuwahara, Y. and Sakai, H. (2004) Changes in Mineral Composition and Depositional Environments Recorded in the Present and Past Basin-Fill Sediments of the Kathmandu Valley, Central Nepal. Himalayan Journal of Science, 2, 222-223. http://dx.doi.org/10.3126/hjs.v2i4.912

[18] Dixit, A. and Upadhya, M. (2005) Augmenting Groundwater in Kathmandu Valley: Challenges and Possibilities. Nep- 
al Water Conservation Foundation, Kathmandu.

[19] Criag, H. (1961) Standard for Reporting Concentrations of Deuterium and Oxygen-18 in Natural Waters. Science, 133, 1833-1834. http://dx.doi.org/10.1126/science.133.3467.1833

[20] Pant, B.R. (2011) Ground Water Quality in the Kathmandu Valley of Nepal. Environmental Monitoring and Assessment, 178, 477-485. http://dx.doi.org/10.1007/s10661-010-1706-y

[21] EMECS (2001) Water Quality Conservation for Enclosed Water Bodies in Japan 2001. International Center for the Environmental Management of Enclosed Coastal Seas (EMECS). http://www.emecs.or.jp/S

[22] WHO (2004) Guidelines for Drinking-Water Quality. Third Edition, Volume 1, World Health Organization, Geneva.

[23] Buss, S.R., Herbert, A.W. and Morgan, P. (2004) A Review of Ammonium Attenuation in Soil and Groundwater. Quarterly Journal of Engineering Geology and Hydrogeology, 37, 347-359. http://dx.doi.org/10.1144/1470-9236/04-005 http://www.researchgate.net/profile/Steven_Thornton/publication/245378357_A_review_of_ammonium_attenuation_i n_soil_and_groundwater/links/54199cd90cf25ebee988773f.pdf

[24] Fernando, T.W. and David, N.L. (2005) Non-Agricultural Sources of Groundwater Nitrate: A Review and Case Study. Water Research, 39, 3-16. http://dx.doi.org/10.1016/j.watres.2004.07.026

[25] Rao, N.S. (1998) Impact of Clayey Soils on Nitrate Pollution in the Groundwater of the Lower Vanisadhara River Basin. India Department of Geography, Andhra University, Visakhapatnam.

[26] Chapagain, S.K. and Kazama, F. (2012) Overview of Chemical Quality of Groundwater in the Kathmandu Valley. In: Shrestha, S., Pradhananaga, D. and Pandey, V.P., Eds., Kathmandu Valley Groundwater Outlook, Asian Institute of Technology (AIT), The Small Earth Nepal (SEN), Center of Research for Environment Energy and Water (CREEW), International Research Center for River Basin Environment, University of Yamanashi (ICRE-UY), Kofu, 49-55.

[27] Environment Statistics of Nepal (2008) A Report Prepared by Government of Nepal. National Planning Commission Secretariat, Central Bureau of Statistics, Kathmandu.

[28] Kirchmann, H. and Pettersson, S. (1995) Human Urine-Chemical Composition and Fertilizer Use Efficiency. Nutrient Cycling in Agroecosystems, 40, 149-154. http://dx.doi.org/10.1007/bf00750100

[29] Yang, L., Song, X., Han, D., Zhang, B. and Long, D. (2012) Characterizing Interactions between Surface Water and Groundwater in the Jialu River Basin Using Major Ion Chemistry and Stable Isotopes. Hydrology and Earth System Sciences, 16, 4265-4277. http://dx.doi.org/10.5194/hess-16-4265-2012

[30] Li, X., Zhang, L. and Hou, X. (2008) Use of Hydrogeochemistry and Environmental Isotopes for Evaluation of Groundwater in Qingshuihe Basin, Northwestern China. Hydrogeology, 16, 335-348. http://dx.doi.org/10.1007/s10040-007-0269-7

[31] Panno, S.V., Hackley, K.C., Hwang, H.H., Greenberg, S.E., Krapac, I.G., Landsberger, S. and O’kelly, D.J. (2006) Characterization and Identification of Na-Cl Sources in Ground Water. Ground Water, 44, 176-187. http://dx.doi.org/10.1111/j.1745-6584.2005.00127.x

[32] Jenkins, D.T., Sharma, C.K. and Hasset, J.M. (1987) A Stable Isotope Reconnaissance of Groundwater Resources in the Kathmandu Valley. Poster Session Presented at on Symposium on Isotope Techniques International Atomic Energy Agency, Vienna.

[33] Kendall, C. and McDonnell, J.J. (1998) Isotope Tracers in Watershed Hydrology. Elsevier, Amsterdam, 839 p.

[34] Negrel, P., Pauwels, H., Dewandel, B., Gandolfi, J.M., Mascre, C. and Ahmed, S. (2011) Understanding Groundwater Systems and Their Functioning through the Study of Stable Water Isotopes in a Hard-Rock Aquifer (Maheshwaram Watershed, India). Journal of Hydrology, 397, 55-70. http://dx.doi.org/10.1016/j.jhydrol.2010.11.033

[35] Yeh, H.F., Lin, H.I., Lee, C.H., Hsu, K.C. and Wu, C.S. (2014) Identifying Seasonal Groundwater Recharge Using Environmental Stable Isotopes. Water, 6, 2849-2861. http://dx.doi.org/10.3390/w6102849

[36] Gajurel, A.P., Lanord, C.F., Huyghe, P., Guilmette, C. and Gurung, D. (2006) C and O Isotope Compositions of Modern Fresh-Water Mollusc Shells and River Waters from Himalaya and Ganga Plain. Chemical Geology, 233, 1-2. http://dx.doi.org/10.1016/j.chemgeo.2006.03.002

[37] Morrissey, C.A., Boldt, A., Mapston, A., Newton, J. and Ormerod, S.J. (2013) Stable Isotopes as Indicator of Wastewater Effects on the Macroinvertebrates of Urban Rivers. Hydrobiologia, 700, 231-244. http://dx.doi.org/10.1007/s10750-012-1233-7

[38] Onodera, S., Kitaoka, K., Hayashi, M., Shindo, S. and Kusakabe, M. (1995) Evaluation of the Groundwater Recharge Process in a Semi Arid Region of Tanzania, Using $\delta \mathrm{D}$ and $\delta^{18} \mathrm{O}$. Application of Tracers in Arid Zone Hydrology (Proceeding of the Vienna Symposium, August 1994), IAHS Publication No. 232, 67-78. 